Du texte à la scène : langages du théâtre

\title{
Thomas Heywood, Shakespeare's shadow: "A description is only a shadow, received by the ear" (An Apology for Actors)
}

\section{M.C. Bradbrook}

\section{(2) OpenEdition \\ Journals}

Electronic version

URL: http://journals.openedition.org/shakespeare/457

DOI: $10.4000 /$ shakespeare.457

ISSN: 2271-6424

Publisher

Société Française Shakespeare

\section{Printed version}

Date of publication: 1 November 1983

Number of pages: 13-34

\section{Electronic reference}

M.C. Bradbrook, «Thomas Heywood, Shakespeare's shadow: "A description is only a shadow, received by the ear" (An Apology for Actors) ", Actes des congrès de la Société française Shakespeare [Online], 4 | 1983, Online since 01 January 2007, connection on 02 May 2019. URL : http:// journals.openedition.org/shakespeare/457 ; DOI : 10.4000/shakespeare.457 
SOCIETE FRANÇAISE SHAKESPEARE

Actes du Congrès 1982

\section{DU TEXTE A LA SCENE : Langages du Théâtre}

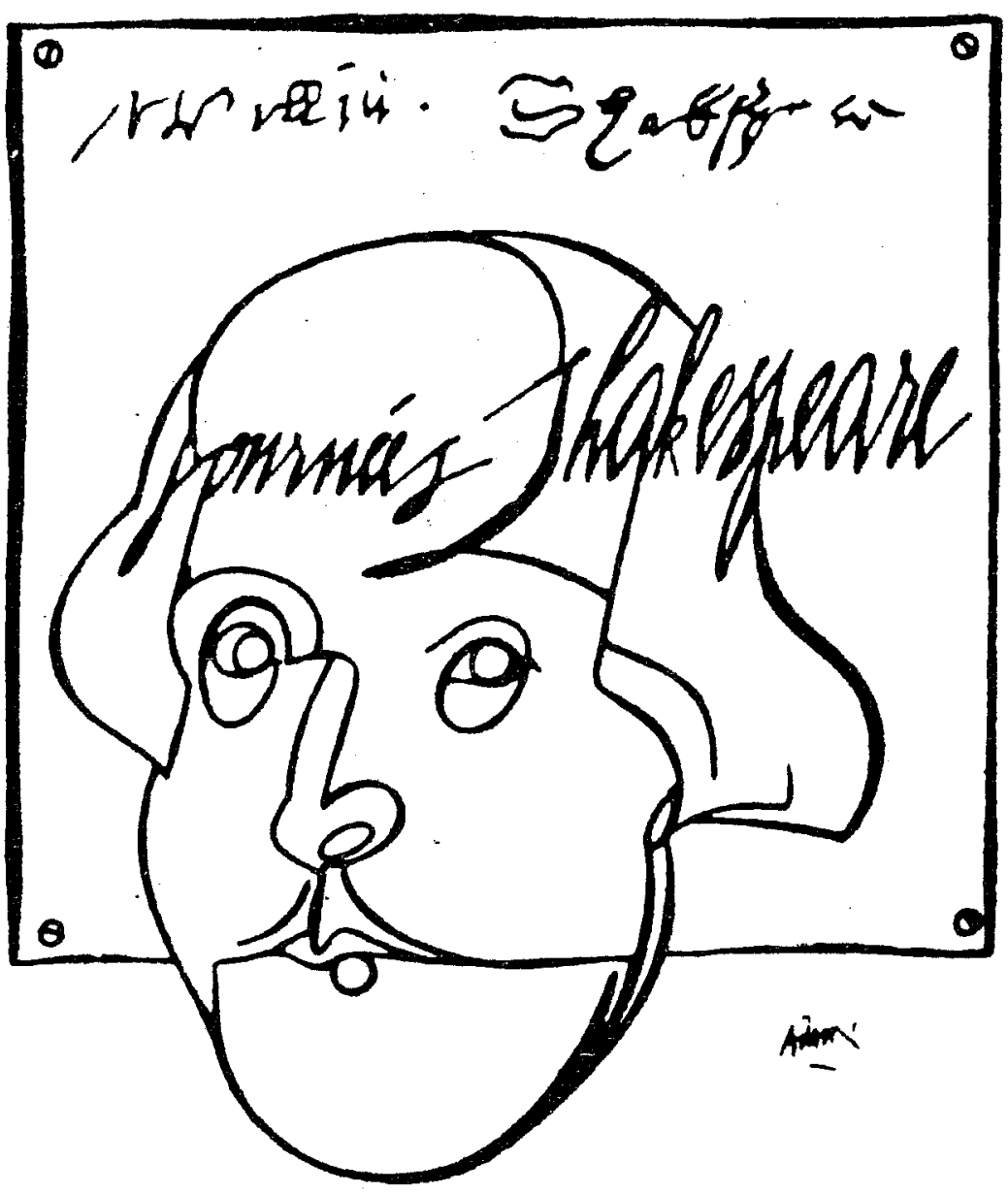

DiRecteur de la publication M.T. Jones - Davies

Publié avec le concours du Centre National de la Recherche Scientifique

JEAN TOUZOT Libraire - Editeur

38 , rue Saint-Sulpice 75278 PARIS CEDEX 061983 


\section{THOMAS HEYWOOD, SHAKESPEARE'S SHADOW, «A DESCRIPTION IS ONLY A SHADOW, RECEIVED BY THE EAR » (AN APOLOGY FOR ACTORS)}

Most conspicuously neglected of Renaissance dramatists, Thomas Heywood has not been edited since 1874, although Arthur Brown and Blakemore Evans both collected materials; his non dramatic works remain uncollected to this day. A clue may be found in the strictures of critics :

... to inform the verse, there is no vision, none of the artist's power to give undefinable unity to the most various material. Of those of

Heywood's plays which are worth reading each is worth reading for itself, but none throws light upon any other. T.S. Eliot, Elizabethan Essays, 1934, p. 107.

It is not - emphatically - a minor nuisance that a young man capable of an interest in literature should be stimulated to work up a feeling of enjoyment when reading the plays of Dekker and Heywood. L.C. Knights, Drama and Society in the Age of Jonson, 1937, p. 256.

Frederick Boas thought «of course he wrote far too much» and Fredson Bowers stigmatized him as «an assembly-line dramatist». The most considerable modern study, that of Michel Grivelet (1957) whilst far more penetrating, points in its subtitle Thomas Heywood et le drame domestique élisabéthain to the works worth reading - his two marital dramas. In the quarter century since Grivelet's essential study, a radical shift in the approach to dramatic texts has shown itself, chiefly in Shakespearean studies. Heywood has an important role, not yet recognised, in this investigation, in supplying such a variety of «Bad» i.e. corrupt texts.

In 1633, approaching sixty, Heywood in a note to The English Traveller pointed out very explicitly that he did not wish to be read. His poetic Troia Britannica, yes; 
his huge folios, The History of Women. The Hierarchy of the Blessed Angels, yes; but of the 220 plays in which he claimed «an entire hand or at least a main finger» only twenty, in battered texts, survive. He resembled Shakespeare in being a sharer in one of the leading London companies, a full professional actor, but his working life of fifty years more than doubled Shakespeare's. He said many plays had been lost by changing of companies, others witheld by their owners, the actors; but also, «it was never any great ambition in me, to be in this kind voluminously read». His dramatic achievement was not transmissible in print; the «undefinable unity» given to «the most various material» occurred in performance. Words alone represented a scenario, an operatic score for a collaborative cultural event, when actors and audience bestowed the final shaping. The ingredients were familiar, the mixture new - this is not «assembly line» activity. The notion of a fully collaborative, multiform rite, a dromenon involving the Muses of Song and Dance, celebrating the community itself is accepted for the Stuart Masque. It is no less obviously true of the seven City pageants composed by Heywood in the 1630s and printed with the motto Redeunt spectacula on each. It is true of his most popular work, The Four Ages (1612), that secular craft cycle of five plays (The Iron Age is a double play, not surprisingly since it covers the Trojan War from the rape of Hesione to the death of Agamemnon).

Only recently have the implications of E.A. Honigmann's The Stability of Shakespeare's Text (1965) been applied, in the editing of the Oxford Shakespeare; the implications for Heywood are vital. Certain plays of Shakespeare e.g. Troilus and Cressida and King Lear surviving in Quarto and Folio texts are seen as representing two valid versions. Stanley Wells, general editor of the Oxford text propounded at Stratford in 1982 that the Quarto of King Lear might be the «authorized»copy, Shakespeare's draft before performance, the Folio a later playhouse text incorporating later revisions, some by him, 
some by others, but in any case an independent version. Conflation of the two for an edectic text becomes a major editorial act of interference. Troilus and Cressida it is thought exists in a Quarto based on Shakespeare's «foul papers» and a Folio text based on a late prompt book ${ }^{1}$. Harold Jenkins's Arden Hamlet curtly dismisses such ideas in a footnote, but this is perhaps the last monument to an old tradition for the modern interest in performance has now impinged upon the last stronghold of «literary» scholars, the text itself. Many of the surviving texts of Heywood appeared years after their first performance, when they were being given in theatres very different from their first venue. The Fair Maid of the West. published 1631 but dated by one of its recent editors as early as 1602 , feels as if it survives in a new version of an old scenario. The «feel» of the dialogue to me is Caroline - here one must be content to be impressionistic - and the choruses suggest that some of the original action - the seafight might have been staged at the Boar's Head or the Red Bull - was cut out for the little Cockpit Theatre.

To reconstitute a dramatic text is an act of cultural archaeology - the recovery of a full context or at the worst a sense of what is now irrecoverable. Heywood repays such an approach.

Beginning to work as an actor bound to Henslowe from Lady Day 1598, he was already known as a dramatist. In 1592-1593 he worked with Shakespeare on the text of Sir Thomas More; it was in the section assigned to him (Hand B) that Shakespeare's famous speech was inserted ${ }^{2}$. Like Shakespeare he remained with the one company, which became the Queen's Men in 1603, later the Lady Elizabeth's, finally in part Queen Henrietta. Maria's. In 1606 the company moved from the Boar's Head to the newly built Red Bull in Clerkenwell, where Heywood took up residence. In 1617 they migrated to the Cockpit, a small indoor theatre in Drury Lane, the first to appear on that historic site. 
Heywood's surviving marital dramas, A Woman Killed with Kindness (1603) and The English Traveller (1633) are worth reading; that is, they can be reactivated in the mind of an attentive reader. In the second both the address to the Reader and the Prologue recognise special claims :

A strange play you are like to have, for know

We use no drum nor trumpet, nor dumb show;

No combat, marriage, not so much today

As song, dance, masque to bombast out a play,

Yet these all good and still in frequent use

With our best poets; nor is this excuse

Made by our author, as if want of skill

Caused this defect; it's rather his self will...

He only tries if once bare lines will bear it.

Condemnation of «bombast», an attitude fashionable with those who scorned the Red Bull shows, conflicts with a sense that it is a defect to trust to «bare lines». The play having accidentally fallen to the press, as Heywood explains, he took the opportunity to dedicate to a very respected friend of his much respected uncle, and to utter a defiance to Prynne's Histriomastix, recently published and widely execrated.

Heywood's concern for family bonds is akin to his own sense of the familial ties within the band of players. His Rape of Lucrece was published «by consent» for it was scarce honest to make «double sale» first to the stage and then to the press. Better however than allowing «corrupt and mangled» copies made by ear. Thirty years later he mused in a prologue for his immensely popular drama on Queen Elizabeth, If you know not me, you know nobody (printed in Pleasant Dialogues and Dramas):

Plays have a fate in their conception lent, Some so short lived, no sooner shewn than spent: But born today, tomorrow buried, and

Though taught to speak, neither to go nor stand. This (by what fate I know not) sure no merit-That it disclaims - may for the age inherit, 
Writing 'bove one and twenty; but ill nurst. And yet received as well performed at first...

So much that some by stenography drew

The plot, put it in print (scarce one word true)... Nathaniel Butter, the «pirate», when reprinting for the seventh time coolly added this prologue and an epilogue, with a few amendments which may have been Heywood's!

This play, brought out soon after the Queen's death (like Dekker's on the same subject, The Whore of Babylon) proved uncommonly durable as theatrical material. Heywood continued to be acted in the same way as Kyd's The Spanish Tragedy or Marlowe's Jew of Malta. It was Heywood who recorded Kyd's authorship of the first and who published the second forty years after Marlowe's death, with a special prologue for his actor friend Richard Perkins, who wanted to revive it, to test himself in one of Alleyn's leading roles. In The Hierarchy of the Blessed Angels (1635) Heywood recalls his fellow poets as Kit, Will, Ben, Jack and ends his list

I hold he loves me best that calls me Tom.

He wrote a General (though summary) description of all poets both foreign and modern, which has perished. The catastrophe of his most famous drama involves what Grivelet termed «l'horreur sacrée qui s'attache à la profanation du foyer» (p. 151), but Heywood's foyer was the foyer of the theatre.

The prologue to $A$ Woman Killed with Kindness (1603) apologizes (in a manner that success alone would justify) for «bareness», whilst the epilogue suggests that opinion will differ; some will judge it «too trivial» some «too gross», just as wine will be judged «new, old, flat, sharp, sweet and sour». Clearly he had a modern theatrical sense of the value of debate in stimulating an audience.

One of his earliest surviving plays (in a ruinous text) is The Famous History of the life and death of Captain Thomas Stukeley (1596, published 1605); the «huffing» adventurer from George Peele's Battle of Alcazar (1589) is shown in London, Ireland, Spain, Rome, Morocco; 
he is recalled again in the second part of If you know not $m e$... as one who "had a spirit equal to a king». He had become one of London's own legends; and these were central to Heywood's communal or familial bonding.

Our Johannes Factotum probably remodelled an earlier Godfrey of Bulloigne for his notorious Four Prentices of London (1600), where not only this Christian member of the Nine Worthies but his three brothers are apprenticed in London, owing to the exile of their father, the Count of Bulloigne. Their adventures all over Europe are really quite impervious to the later burlesque of Beaumont in The Knight of the Burning Pestle; they are first in the line that leads to The Magnet and The Gem to Billy Bunter and Harry Wharton.

If Heywood began with romance and chronicles, by the turn of the century he had learnt much about the art of playwriting. When in 1602 he was signing receipts for court payment of the Earl of Worcester's Men (later Queen Anne's Men) he had already joined the group whose outstanding feature was that it was always to be led by a clown. Kempe was succeeded by Thomas Greene, he by William Rowley, who wrote plays. Greene was thin and Rowley fat, but both had to have «fat» parts in any play.

Heywood's characteristic lines are the sympathetic heroine, whether a «fallen woman» like Jane Shore in King Edward $I V$ and Mistress Frankford, or a martyr of constancy, like Princess Elizabeth; and the young prodigal, who appears in Stukeley, in Sir Thomas Gresham's nephew in Part II of If you Know Not Me, young Chartley in The Wise Woman of Hogsden and Young Lionel in The English Traveller.

The Fair Maid of the West is in many ways a modern romance; it could be termed the first Western. The subtitle «A girl worth Gold» indicates that although virtue takes first place, riches are not neglected. The irresistible Bess Bridges of Plymouth is ensured a fortune whether running an English tavern, or leading her ship's crew (all ena- 
moured to a man) to victory on the Spanish Main. She is plainly deputy for a greater Elizabeth; and when everyone is united at the court of Fez, the fortunate presence of a captive clergyman enables her to be joined with her long lost lover, whilst the Clown, eager for honour, finds out just in time what is involved in being Chief Eunuch. Bess's charms both inflame and subdue the King, no one ever really gets hurt; in spite of its apparent artlessness, the artifice of the game is firm enough

Young Chartley of The Wise Woman of Hogsden outgoes most of the wild youths of this kind of comedy in pledging himself to three brides at once ${ }^{4}$. The final scene exposes him to each in turn, and he finds that he has apparently married a boy-who, however, is Bride No I in disguise. Although he makes Bertram of Roussillon look like a model of restraint and self control young Chartley is allowed a sudden repentence at the end of a most skilfully contrived farce in the Feydeau style, the scene being what is fairly obviously the Wise Woman's brothel. Its permissiveness, banishes finger wagging at Prodigal Sons and contrasts very notably with the near contemporary Measure for Measure, or the cynicism of Chapman's The Widow's Tears. The latest of such stories, the subplot of The English Traveller, gives names from beast fable to Young Lionel, his clever servant Reynard (the Fox). The fable is Plautine and the old father who has secretly witnessed his son's wildness is crowned with a coxcomb before being recognised; but none the less forgives all.

Heywood was perfectly capable of neat and well articulated joining of plot and subplot (as in $A$ Woman Killed with Kindness which can be dated precisely February 1603); in the later play, it is the contrast between youth and age in tragic mainplot and subplot that gives a kind of bonding. Heywood knew better than most the art of projection. His plays are conceived for effect, for establishing rapport; there is something for an actor to give his audience. His most characteristic and 
most skilful use of control lies in the poignant reticence of grief in his wronged husbands or his constant women. A single repeated word perhaps represents a stage sob; Frankford's «Oh, Nan, Nan!», Bess Bridges' address to her lover's picture :

... when none save the bright stars

Were up and waking I remembered thee

But all, all to no purpose.

In a culture not illiterate but very largely oral, Heywood's plays are largely opaque to the present age. What now of course is most opaque is the spectacular element, the stage language of gesture, blocking, emblematic costume, the familiar appeals to a London scene. If playmakers relied on the marriage of image and speech (the «device» of early Tudor shows), for Heywood there was no contest between poet and painter. In so far as he thought at all, he thought pictorially, in terms of spectacle, from The Four Prentices of London to his last great success, Love's Mistress (1634) where he enthusiastically acknowledged in his dedication the collaboration of Inigo Jones. His more usual partner was Gerard Christmas, the Inigo Jones of the City, with whom he worked not only upon the Lord Mayor's pageants, but on the decoration of a warship, Sovereign of the Seas : for Christmas was official painter to the Royal Navy.

In Popular Culture in Early Modern Europe (1978) Peter Burke devotes a section to «the Triumph of Lent over Carnival» or the «petty bourgeois ethic» as he terms it over a tradition «harder to define because of generosity and spontaneity and a greater toleration of disorder» (p 213). In Heywood the conflict seems to have been reconciled. He could not but give a leading role to Disorder in the person of Will Kempe, Thomas Greene or William Rowley, the fat clown who was also a dramatist (and with whom he collaborated) : with the curious results, already seen in The Rape of Lucrece, 1607, where hornpipes and funerals are bewilderingly alternated. The editor of The Old English Drama suggested that - like the 
poet of Histriomastix - Heywood wrote the play in drink; but it was widely successful and in 1612 formed part of a double bill at court, with the story of Alcmena's innocent adultery (The Silver Age). For this performance the King's and Queen's Companies joined; Shakespeare and Heywood may have played together.

Heywood's admiration for Shakespeare is attested in his earliest poem Oenone and Paris, registered 28 May 1954, when he was 21, a blatant imitation of Venus and Adonis. When he wrote his Tragedy of Lucrece, his printer friend Nicholas Okes had just reissued Shakespeare's poem The Rape of Lucrece. Heywood's admiration for Shakespeare the poet is made plain; his bashful serving man, however, becomes Heywood's clown (Brutus assumes clowning). There are large debts to Lady Macbeth and to Goneril in Tullia's part; her «There is no earth in me, I am all fire» is Cleopatra's. But the pith of the performance was the songs, which were constantly being increased; it is as though Lear's Foolwere allowed to swamp the play. There is one about the taverns of Rome; one on «The Cries of Rome» which include «Bread and meat, bread and meat, for the tender mercy of God, to the poor prisoners of Newgate, four score and ten poor prisoners!»-followed by «Salt, salt, white Worcestershire salt !» The three-man catch in which the clown betrays Lucrece's rape to Valerius and Horatius (he has sworn to say nothing) opens:

Valerius : Did he take fair Lucrece by the toe?

Horatius;:Toe, man?

Valerius : Ay, man.

Clown : Ha, ha, ha man, fa derry derry down, ha fa derry dino!

The clown enjoys a particularly direct, electrical contact with the audience. It can be dangerous. It is stronger than the relation of any other player; the clown therefore challenges the playwright; Heywood accepted the relationship.

The outrageous catch immediately precedes the death scene of Lucrece. It may be that Heywood was 
remembering the Porter's scene in Macbeth, without grasping what Shakespeare had done with his ironic clowning there.

It is extremely difficult to know how Heywood approached this story. Recently, critics have been concerned with Webster's use of «clashing tones», with the «horrid laughter» that reverberates in Revenge tragedy at this time ${ }^{5}$. Heywood's juxtapositions are far more discordant and shocking than anything in Tourneur or Webster. Yet these men were friends (their elegies for Prince Henry were to be bound up together and issued in a single volume when a tragic occasion in actual life called them to express unambiguous grief). Webster in my view imitated Heywood in his Appius and Virginia ${ }^{6}$, Collatine's advice to his friends that under tyranny they should wear out our hours in harmless sports...

So shall we seem offenceless and life safe (4.3.) may refect upon the fate that had overtaken the choristers' theatres, mainly through the political implications of Chapman's plays.

Heywood's most spectacular success, The Four Ages, which dramatized his own verse history, Troia Britannica, also used many familiar dramatic stories; the Twelve Labours of Hercules had been cited twenty years earlier by the upstart player in Greene's Groatsworth of Wit (1593) as a part in which he «thundered terribly». Chapman's translation of Homer was also drawn on (Homer appeared as Presenter in the first play) but even more freely, the dramatic stage successes of William Shakespeare (including Hector's treacherously contrived death). Two troupes were required to stage this gigantic series; the capital outlay must have been considerable, but success was assured. And at the end all was related home to London once more, as the Ghost of Hector prophesied to Aeneas that his descendants should build New Troy on the banks of the Thames. This work represented Heywood's crowning achievement to his contemporaries, until the advent of Love's Mistress in his 
latest years. The Shakespearean lines must have been gleaned in the playhouse, since Othello, Macbeth and The Tempest, which are laid under contribution, were not in print. Saturn's wife, preparing to sacrifice the infant Jupiter at her husband's command exclaims «I'll kiss thee ere I kill thee !» Medea invokes a

Goddess of witchcraft and dark ceremony,

To whom the elves of hills, of brooks, of groves, Of standing lakes and caverns vaulted deep

Are ministers, three headed Hecate ...

That by incantations can remove

Hills from their seats, and make huge mountains shake,

Darken the sun at noon, call from their graves

Ghosts long since dead ...

It may be seen from the edition by Arlene W. Weiner (1979), that The Iron Age is even more heavily indebted, with Clytemnestra echoing Gertrude, Thersites appearing from Troilus and Cressida (almost the only railing character in Heywood). Sinon's «A horse, a horse» is capped by Pyrrhus with «Ten kingdoms for a horse to enter Troy!» but the famous line from. King Richard III was by then common property. The text of this, the last of the Ages, did not appear till 1631, by which time Homer as Presenter has disappeared. The ghost of Agamemnon appears as his son is about to kill Clytemnesta, who thinks her son is mad because she can see nothing. She is killed, Helen commits suicide, and Ulysses is left, with Aeneas, future founder of New Troy, as sole survivors.

In view of his Autolycus-like picking from Shakespeare's repertory, Heywood's rebuke to the printer Jaggard at the end of An Apology for Actors is not without a touch of comedy. Two epistles from Heywood's poem Troia Britannica, were added to The Passionate Pilgrim in 1612, ascribed to William Shakespeare. It might be thought, Heywood protested, that he had stolen them from Shakespeare, who was taking them back! But he knew Shakespeare to be «much offended with M. Jaggard, 
that altogether unknown to him made so bold with his name». Various other well-known lyrics, including «Come live with me and be my love» were added by Jaggard, who subsequently took Shakespeare's name off the title page. Shakespeare continued to furnish Heywood with material : The Captives ( 1624) is based on Plautus, but the two chaste heroines immured in a brothel have a clear stage ancestry in Pericles whilst the subplot comes from The Jew of Malta. Only once, I think did Heywood improve a line of Shakespeare, when in Troia Britannica E6 «Tis double death to drown in ken of shore» (Rape of Lucrece 1114) becomes "Tis double death to drown in sight of shore».

The Golden Age was pirated and printed in 1611 by William Bullinger; Nicholas Okes, Heywood's printer friend, who specialized in play books then printed two more of the series. His text may be relied upon.

The two parts of The Iron Age were not printed till 1631 when Heywood observed:

I know not how they may be received in this age where nothing but Satirica Dictaeria and Commedia Scommata are now in request; for my own part, I never affected either when they stretched to the abuse of any person, public or private.

He was happier to praise; and it was possibly the great success of his Four Ages which encouraged him to publish in 1612, again from the press of Nicholas Okes, his Apology for Actors. It would appear from the concluding rebuke to the choristers' companies for their scurrility that it was written before they disappeared; but here it is the energy generated by the sight of his own success that transports Heywood.

A description is only a shadow, received by the ear but not possessed by the eye; so lively portraiture is merely a form seen by the eye, but can neither show action, passion, motion, or any other gesture to move the spirits of the 
beholder to admiration;but to see a soldier shaped like a soldier, act like a soldier ... to see, as I have seen, Hercules in his own shape hunting the Boar, knocking down the Bull, taming the Hart, fighting with Hydra,murdering Geryon, slaughtering Diomede, wounding the Stimphalides, killing the Centaur, pashing the Lion, squeesing the Dragon, dragging Cerberus in chains, and lastly on his high Pyramides writing Nil Ultra, $\mathrm{O}$ these were sights to make an Alexander (B3v-B4r)

His Apology does not tell later generations much about the form of the Jacobean theatre; it is itself a spectacular demonstration of the public role of actors; the great dignity and glorious ancestry of the profession is paraded. Webster supports his «beloved friend», the leading man of the Red Bull, dashing Richard Perkins, and Christopher Beeston also contribute praises, whilst Heywood commends the printer Nicholas Okes (Heywood's hand was almost illegible).

Although the Apology called forth an immediate refutation from a precisian, its appearance registers a modest confidence. Several actors by now were vestrymen, or churchwardens in their parishes. It may be that even Ben Jonson was not above noting Heywood's success; in January 1615 his court masque was entitled The Golden Age Restored. It is however the Caroline Heywood, who shows the most astonishing proofs of his theatrical competence; for he not only penned the seven mayoral triumphs which were probably the most directly influential of all his spectacles, he also wrote the courtly and sensitive drama of The English Traveller, a complete transformation of the theme of his earlier marital plays; and he achieved a court triumph in his sixty second year with Love's Mistress, variously known as Cupid and Psyche, The Queen's Masque.

Henrietta Maria offered the play as birthday entertainment for the King at Denmark House on 17 November 1634; they had already seen it at the Cockpit, and saw it 
a third time within a few days. This remarkable fruit of forty years' playwriting has been fully discussed in its ritualist and Neo-Platomic aspects by Jackson Cope. ${ }^{7}$

Although it was spectacular, and the settings devised by Inigo Jones, Psyche's labours could not rival the labours of Hercules, nor perhaps even «Medea hanging in the heavens with strange fiery works in the habit of a conjurer», Six different sorts of ass dance in an antimasque; six «contrary» characters, victims of love, give the corps de ballet a second dance. Scenes in Vulcan's forge and at the infernal court of Pluto : a singing contest, lost by Apollo to the Clown; a final assembly of the Seven Planets to do homage to the King and Queen (in imitation of Carew's court masque of the last February, Coelum Brittanicum) decorate the story itself, which is expounded in entr'acte discussions of Apuleius with Midas (representing ignorance). This is Jonsonian but the theme itself recalls the Emblems of Francis Quarles, published this year. Illustrations to Quarles, especially the Fool with childish winged Amor and Anima in Book II, Anima climbing the hill to the tower (Book IV, emblem II) or the repentent figures in garments of tears (Book $V$, emblem V) look forward to the magnificent plates Heywood was himself to use in his Hierarchy of the Blessed Angels (which Cowley was later to link with Quarles ). But the plot is light and airy; Psyche pardons her two wicked sisters instead of consigning them to a horrid death as in Apuleius; when the play was revived at the Restoration Pepys saw it no less than five times, particularly praising its «good variety» - «full of variety and divertissements». The Clown is as predominent as ever; a bastard son of Midas, first he defies Amor, is thrown in love with a hideous old hag (like Sir Tophas in Lyly's Endymion) then purloins a Box of Beauty (full of «ugly painting») with which he spots his face like the clowns in the plays of Redford a hundred years earlier. Pepys greatly enjoyed the «jeer» with which he parodied Heywood's own Trojan tragedy : 
This Troy was a village of some twenty houses ... by this Troy, ran a small brook that one might stride over. On the other side, dwelt Menelaus, a farmer who had a light wench to his wife ... (II.iii.40-55)

A little earlier he had seemed to recall Berowne's railing on Cupid ( II.iii.20-7; cf Love's Labours Lost III.ii.164-95 ). Psyche's cry as she sees the beauty of the sleeping Cupid «Churl beauty, beauteous niggard》 seems close to the language of the Sonnets;

However the most considerable borrowing is from a lost play Cupid and Psyche, by Dekker, Chettle and Day written in 1600 for the Admiral's Men, and recorded in Henslowe's Diary. This would have gone quite undetected but for the chance that a portion of the text has survived; it is quoted by Raymond Shudy in his edition of Heywood's play.

The original, if it survived so long, would have perished in the fire which in 1622 destroyed the Fortune theatre and all the players' repertory. In view of Heywood's strictures to Jaggard in 1612 about The Passionate Pilgrim, his practice in 1634 must seem to mark a total distinction between speech and print. Here is the passage signed Thomas Dekker, in England's Parnassus (1600)

Sacred Apollo, God of Archery, Of Arts, of pleasure and of Poetry, Jove's fair haired son, whose yellow tresses shine,

Like curled flames; hurling a most divine And dazzling splendour, in those lesser fires Which from thy gilt beams when thy Car retires Kindle those tapers that lend eyes to night, $O$ thou that art the Landlord of all light Bridegroom of morning, day's eternal king, To whom nine Muses ( in a sacred ring) In dances spherical trip hand in hand, Whilst thy seven stringed lute their feet 
Whose motion such proportioned measure bears, That to the music dance nine heavenly spheres.

Great Delian priest, we to adore thy name, Have burnt fat thighs of bulls in hallowed flame, Whose savour wrapt in smoke and clouds of fire To thy star spangled palace did aspire. And here is Heywood's adaptation Love's Mistress

Sacred Apollo, God of Archery, Of arts, of physic and of poetry :

Jove's bright haired son, whose yellow tresses shine

Like curled flames, hurling a most divine And dazzling splendour on these lesser fires, Which from thy gilt beams, when thy car retires, Kindle those tapers that lend eyes to night; $\mathrm{O}$ thou that art the landlord of all light, Bridegroom to morning, day's eternal king, To whom nine muses, in a sacred ring, In dances spherical, trip hand in hand Whilst thy well stringed harp their feet command: Great Delphian priest, we to adore thy name Have burnt fat thighs of bulls in hallowed flame, Whose savour, wrapped in clouds of smoke and fire,

To thy star spangled palace durst aspire.

There is a shorter passage of five lines copied with the same literalness in II. i. 5-9.

When many a weary step

Had brought us to the top of yonder mount, Mild Zephirus embraced us in his arms, And in a cloud of rich and sweet perfumes, Cast us into the lap of that green mead.

When many a weary step Had brought us to the top of yonder rock Mild Zephirus embraced us in his arms And in a cloud of rich and strong perfumes 
Brought's unto the skirts of this green mead

An actor must perforce have many lines at his power to recall; and how much came from this lost play we simply do not know. Theatre material was regarded it seems as common property within the theatre, however «dishonest» it might be to print it elsewhere. In a play originally commissioned by Henslowe in May 1600 from Dekker, Chettle, and John Day none of the original three could retain any strong sense of ownership. Does this signal the «death of the author» in theatrical terms? No, I think not. The two theatrical friends who edited Shakespeare's first folio did their best for him; and after all, behind that work is some one called William Shakespeare (in my view, it was William Shakespeare and not anyone else); behind Heywood's plays there is a consistent approach to the material; the same is true of other actor-dramatists like Rowley and Brome.

One must remember too that Shakespeare's texts (with others) were adapted in the second half of the seventeenth century very freely, and these versions ought not to be looked on as debased Shakespeare but as evidence of what the theatre of that time was like. The first edition of Dryden's Troilus and Cressida or Truth found too Late 1679 is prefixed by the following verses from one Richard Duke:

...Shakespeare 'tis true this tale of Troy first told,

But as with Ennius Virgil did of old, You found it dirt but you have left it gold.

A dark and indigested heap it lay, Like Chaos ere the dawn of infant day, But you did first the cheerful light display.

Confused it was as Epicurus' world Of atoms by blind chance together hurl'd, But you have made such order through it shine As loudly speaks the workmanship divine.

Dryden's essay prefixed to this work is the fullest 
statement of the new position in regard to tragedy; by making Cressida loyal, and killing everybody at the end ("they all die upon the place, Troilus last») he followed the model of his better known version of Antony and Cleopatra, without quite reaching the extremes of The Tempest or The Enchanted Island.

Most ephemeral though in their day not least influential of Heywood's plays were the Lord Mayor's Triumphs of 1631-1639, for which he devised a regular and simple form ${ }^{9}$ - the water pageant, the opening speeches, the antimasque, the main action and the conclusion. The last of the series, London's Peaceable Estate, 1639, celebrates a Lord Mayor who had travelled to Greenland, Muscovy and Turkey. The City's plantations in Ireland, Virginia, the Bermudas testify that the adventurous spirit of the still popular Fair Maid of the West passed to London merchants. The River Nile makes an appearance, allowing a long digression upon the habits of the crocodile, but the heart of the matter is a warning against domestic warfare; we should pray for peace

Lest that too late (having stern war accited)

We wish that peace which (while we had)

we slighted.

John Okes, son of Nicholas, was now publishing Mayoral Triumphs, of which this was to prove the last; fortunately for Heywood, he was buried (as «Thomas Heywood, Poet») in his parish church of St James Clerkenwell 16 August 1641, a year before the King raised his standard at Nottingham.

Heywood was at once fluent and adaptable in his response to pressure, his acceptance of convention providing a bulwark against dissent. His talent instantly answered the helm of public demand, whilst the wooden walls of his defensive orthodoxy in matters civic, moral or religious proved quite impregnable to any storms of controversy. He was uniquely qualified to adapt the pageant devices, the non verbal theatrical language always more conservative than speech - to the mood of 
the time, whilst preserving its continuity. He was as fluent as his friend Webster was slow, the shapeless profusion of some of his latest encyclopedic miscellanies taxing even that tolerant age. Outside drama he could not achieve a form; his works are either rigid or amorphous.

Much new information has recently come to light on Heywood's theatres, the Boar's Head, the Red Bull, the Cockpit; and much more detailed study has been made of the various printers, especially of Nicholas Okes ${ }^{10}$. If this were applied to the critical sifting of Heywood's texts, more especially those which have not appealed in terms of their literary qualities, the general relation of the theatre and the published texts might be clarified. It is possible that after the relative paucity of his output in the years 1614-1624, Heywood achieved the status of print because of that wave of Caroline nostalgia for the times of Elizabeth which has been remarked in the later works of Ben Jonson ${ }^{11}$. Heywood was sixty in 1633, a Nestor of the stage. The one really serious revision he made when after thirty-five years he turned his attention to the pirated text of If You Know not me ... was to improve the account of the Spanish Armada, and make it the climax (incidentally, the players were now using this bad text in the theatre, the original presumably being lost!) ${ }^{12}$

Shakespeare speaks to every part of the world; the art of Heywood, though his medium was complex, was nearly as ephemeral as the actor's. It may illuminate Shakespeare's later romances - plays of the gaps especially Pericles with its theatrical power to raise corrupt and broken dialogue in the romance's combination of the exotic and the familiar, the extremes of intimacy and violence.

If a poet is a maker, Heywood merits the title, though his preference for performance leaves him but Shakespeare's shadow. The fact that in Eliot's terms, none of his plays throws light on any other - an overstatement, but understandable, depends on the exact adjustment 
of each moment of dramatic life by his sense of the theatre; for he was its servant, and not, like Shakespeare, its master.

To my uninstructed mind, the fifty years of his dramatic career offer an unexplored field for the modern sophisticated resources of theatrical archaeology and sociology, knowledge of the technique of Renaissance printing which computer research supplies, and modern linguistic interests to unite for a joint exploration in depth.

The Heywood of his own day was not the Heywood who meagrely shows himself among the lesser figures of the stage. Those enormous and very expensive folios, Nine Books of Various History Concerning Women (1624) were delicated to his first patron, the Earl of Worcester, 13 revised by Milton's nephew Edward Philips, and reshaped by Heywood himself in 1640 as The Exemplary Lives and Memorable acts of Nine the Most Worthy Women of the World. Each book was named after one of the nine muses. The Hierarchy of the Blessed Angels (1635) an even larger folio, was dedicated to the Queen. These works far outmeasure the printed remains of Shakespeare and Jonson combined.

Yet Heywood clearly held sympathies with the City fathers who were to oppose the King in the next decade. Perhaps he would himself have justified his limiting his interest in the words of Cicero that he quoted in his Apology for Actors: «Content thee, Caesar, there be many heads busied and bewitched with their pastimes now in Rome, which otherwise would be inquisitive after thee and thy greatness».

M.C. BRADBROOK 
NOTES

1. «The one and Future King Lear» delivered by Stanley Wells at the biannual Shakespeare Conference August 1982 will be published in Shakespeare Survey; for Troilus and Cressida, see the article by Gary Taylor in Shakespeare Survey 1982 and the new Oxford text ed. Kenneth Muir (1982)

2. See the edition by V. Gabrieli and G. Melchiori (Bari, 1981 ); they are now preparingan edition for the Revels Plays

3. The influence of Peele(son of a pageantwriter, himself a deviser of London pageants) was such that he himself became a London legend and appears in The Puritan (1606, Paul's) under the name of George Pyeboard (a peil being a baker's shovel)

4. Cf Matheo in The Honest Whore, young Flowerdale in The London Prodigal, various figures in Westward Holand Northward Ho! Young Thornley in The Witch of Edmonton is a tragic variant

5. See Nicholas Brooke, Horrid Laughter in Jacobean Tragedy (1979), Jacqueline Pearson, Tragedy and Tragicomedy in the Plays of John Webster (1979)

6. Webster here used an innocent story to make a political comment (see my John Webster, Citizen and Dramatist, 1980 , pp. 177-179)

7. Jackson I. Cope The Theater and the Dream, from Metaphor to Form in Renaissance Drama (Baltimore 1973).See also the edition by Raymond C. Shudy (Salzburg, 1977) and his article in Elizabethan Theatre VII, ed. G.R. Hibbard (Macmillan of Canada 1979 .

8. See the edition of Madeleine Doran in the Malone Society Reprints.

9. Cf $m y$ article, «The politics of Pageantry» in Poetry and Drama 1500-1700 ed, A.Colem an and A.Hammond, 1981 , for earlier pageants: in 1612 Heywood supplied verses in the first English Em blem Book, H. Peacham Minerva Britannia.

10. See the work on the Quarto of King Lear by P.M.W. Blayney, Cambridge 1982 .

11. See Anne Barton, «Harking back to Elizabeth; Ben Jonson and Caroline Nostalgia» English Literary History vo1. 48, p. 706-31 (Baltim ore 1981)

12. Quarles and Heywood, instead of «exalting poetry, profaned divinity . 
13. Edward Somerset, Earl of Worcester (1553-1626) succeeded Essex as Queen Elizabeth's Master of the Horse, presided at the treason trials of 1605 , and was Lord Great Chamberlain at Charles I's coronation. He was the father of the two brides celebrated in Spenser's Prothalamion; his wife was a daughter of the Earl of Huntingdon, and Heywood dedicated to him the work on good women as having been «the happy husband and fortunate father of such». 